\title{
DOMINASI PENGILANG CINA DALAM PENGELUARAN BERAS DI KEDAH, 1909-1941
}

\author{
Rozaini binti Ahmad \\ Ahmad Kamal Ariffin Mohd Rus
}

\begin{abstract}
This paper will study the extent of the Chinese rice millers' exploitation of Malays. This discussion is based on the historical method and analysis. Therefore, primary sources such as the Kedah Annual Report (KAR), British Colonial Office Files, periodicals, and The Malayan Agricultural Journal were used. Based on the sources referred, rice planting was the domain of the Malays even before the arrival of the Chinese. However, the arrival of the Chinese and the subsequent establishment of the Chinese rice millers encouraged the rice planting activity. The research revealed that the Chinese millers, while providing a service to the Malays, also exploited them. Malay farmers were bound to Chinese millers as they have to sell their rice to the millers at a cheap rate, which meant losses for the farmers. The lack of technology and the long distance to market their rice produce also forced the Malay farmers to depend of the Chinese millers, even if the prices given were low. Around the 1920s, Chinese millers were expanding rapidly, while Malay farmers remained disadvantaged and burdened by debt. Here it is clear that Chinese millers, which were expected to help the Malays develop rice planting had acted differently, hence reminding one of the Malay saying, "Harapkan Pagar, Pagar Makan Padi".
\end{abstract}

\section{Pengenalan}

Kedah terkenal sebagai "Negeri Jelapang Padi" kerana aktiviti ekonomi utama masyarakatnya adalah penanaman padi. Selain itu, Kedah juga terkenal sebagai pembekal padi yang utama di Tanah Melayu dan penghasilan padi ketika itu berpusat di Kota Setar, ${ }^{1}$ penanaman padi di Kedah menjadi penting sejak abad ke-17 lagi dan sejarah awal menunjukkan tanaman ini bermula di Sungai Muda dan Merbok yang kemudiannya telah berkembang ke seluruh dataran Kedah. Seperti mana yang dinyatakan oleh R. O. Winstedt menerusi bukunya dalam The Malays a Cultural History menyatakan bahawa penduduk Kedah dan Kelantan telahpun menjalankan kegiatan penanaman padi sejak mereka dijajah oleh Kerajaan Sri Wijaya. ${ }^{2}$ Sementara itu, hasil tanaman padi Kedah bukan sahaja dibekalkan dalam negeri malah turut dijual ke bahagian-bahagian lain di Semenanjung Tanah Melayu. Misalnya, pada tahun 1512 dikatakan bahawa negeri Kedah merupakan negeri yang membekalkan paling banyak padi berbanding negeri-negeri lain. Manakala Winstedt juga menerusi penulisan beliau Notes on the History of Kedah menyatakan semenjak berlaku kekurangan beras di Melaka pada tahun 1642, pihak Belanda telah membeli beras dari Kedah bagi menampung kekurangan tersebut. Selain itu, menurut Bonney, eksport beras dari Kedah pada tahun 1785 dianggarkan sebanyak 80,000 pikul dan Pulau Pinang salah sebuah negeri yang menerima eksport beras dari Kedah pada tahun tersebut. ${ }^{3}$

Selanjutnya, sebelum kedatangan British, dapat dinyatakan bahawa pada era Sultan Ahmad Tajuddin Mukarram Shah III, 1854 hingga 1879 merupakan titik permulaan permodenan negeri Kedah. Perubahan yang positif telah memberi hasil yang baik sehingga menjadikan Kedah sebagai negeri yang makmur dari segi ekonomi, aman, dan stabil dari aspek sosiopolitiknya. ${ }^{4}$ Oleh sebab itu dalam tempoh 25 tahun pemerintahan, baginda begitu mementingkan aspek ekonomi dan pentadbiran negeri. Oleh itu, pada peringkat awal dalam 
aspek penanaman padi, sultan bertanggungjawab menentukan segala-galanya terutamanya soal pembesar-pembesar yang terlibat dalam mengawal hasil pengeluaran padi di Kedah. Baginda melantik pembesar-pembesar daerah dalam kalangan kerabat diraja untuk melakukan kawalan tersebut. Antara daerah penting yang menyumbang kepada pengeluaran padi di Kedah ialah Alor Setar dan Kuala Muda. Misalnya, di Alor Setar yang merupakan pusat pengeluaran padi merupakan daerah diraja dan Kuala Muda pula di bawah perintah pembesar Tunku Abdul Rahman. ${ }^{5}$ Para pembesar mendapat tanah 'ampun kurnia' dan mereka membenarkan masyarakat mengusahakan tanah tersebut sekiranya mampu memberikan hasil yang baik. Selain itu, dalam era pemerintahan ini juga langkah yang sesuai telah diambil oleh sultan dengan menggalakkan orang Cina untuk berhijrah ke Kedah bagi membantu perkembangan ekonomi negeri.

Walau bagaimanapun, penglibatan orang Cina dalam perkembangan pertanian padi sebenarnya sebelum 1909 lagi, di mana mereka telah mula mendominasi pengeluaran padi namun pengeluaran hanya berlaku dalam skala yang kecil. Keadaan ini disebabkan, pada peringkat awal orang Cina memberi perhatian terhadap kegiatan perlombongan bijih timah khususnya di Kulim. Maka, dalam perbincangan ini akan memberi fokus terhadap bagaimana orang Cina yang pada peringkat awal terlibat secara kecil boleh mendominasi pengeluaran padi di Kedah. Manakala, apakah impak terhadap para petani Melayu pula setelah orang Cina mula meluaskan pengaruh mereka.

\section{Pengeluaran Padi Sebelum Kedatangan British}

Berdasarkan kegiatan eksport yang dijalankan di pelabuhan-pelabuhan menunjukkan sektor ekonomi pertanian dan perdagangan telah berkembang dengan pesat pada era pemerintahan Sultan Ahmad Tajuddin. Baginda telah memberi tumpuan yang penting terhadap kegiatan pengeluaran padi seperti mana yang telah dinyatakan di dalam Undang-Undang Paduka Tuan pada 1667 yang menekankan mengenai penanaman padi. ${ }^{6}$ Saranan tersebut telah memberi kesedaran kepada orang Melayu untuk menggiatkan diri mengusahakan penanaman padi. Namun penglibatan awal mereka dilihat memberi kelebihan kepada pembesar dalam mengawal dan menguasai para petani. Seterusnya, melihat corak kegiatan penanaman padi dalam kalangan orang Melayu, para petani didapati tidak mendapat pulangan yang tinggi dalam kegiatan tersebut. Walaupun hasil pertanian padi yang diperoleh adalah hasil titik peluh petani, akan tetapi keuntungannya dimiliki oleh pembesar-pembesar. Malah bidang tanah yang telah diusahakan juga bukan hak milik mereka. Petani hanya mengusahakan tanah yang diarahkan oleh pembesar sahaja. Sekiranya rakyat ingin mengusahakan tanah pertanian tersebut haruslah menyerahkan sebahagian hasil tersebut kepada pembesar sebagai balasan kerana menggunakan tanah.

Penguasaan sultan dan pembesar terhadap para petani sebelum kedatangan British merupakan faktor utama dalam pengeluaran padi di Kedah. Petani-petani yang sentiasa bekerja mengusahakan tanah pertanian adalah semata-mata untuk memenuhi keperluan asas mereka sahaja. Ketika itu, para petani turut dilihat ditindas apabila segala hasil pengeluaran padi mereka tidak dikomersialkan akan tetapi hanya menyerahkan beras sahaja kepada pembesar-pembesar. Dengan itu didapati pada akhir abad ke-19, ekonomi bagi sektor pertanian padi negeri Kedah telah mulai rancak. Pada masa ini juga telah dilaksanakan sistem kerah, pajakan, hamba, orang berhutang, ampun kurnia ${ }^{7}$ dan pelepasan cukai terhadap mereka yang sepatutnya. Keadaan ini berlaku apabila pembesar mengambil langkah bagi meningkatkan jumlah bekalan padi dalam negeri. Dengan itu setiap petani Melayu diharuskan terlibat dalam jaringan komersial iaitu sebagai pemegang pajak dengan cara berhutang. Kemudiannya, didapati pihak pembesar menggunakan cara paksaan terhadap petani. Setiap hasil yang diperoleh harus diserahkan sebanyak 1/10 daripada hasil kepada pembesar. Cara paksaan yang digunakan telah menyebabkan rakyat tani tidak mengalami sebarang perubahan 
dalam kehidupan mereka. Ini jelas menampakkan pihak pembesar menggunakan pengaruh dan kuasa mereka mengikat petani melalui dalam sistem kerah. ${ }^{8}$ Manakala, dapat dijelaskan juga apabila semakin penting kegiatan pertanian di Kedah maka semakin bertambah kuasa pembesar terhadap para petani.

Dalam hal ini, pembesar-pembesar didapati berterusan menguasai para petani disebabkan pada abad ke-19 kawasan-kawasan baru untuk tanah pertanian padi dinyatakan perlu ditambah. Ini disebabkan, sultan dan pembesar memerlukan pendapatan yang tinggi untuk membiayai kehidupan mereka, misalnya melakukan pembelian barangan eksport contohnya kain, barang kemas, barang perabot dan sebagainya. Keadaan tersebut telah mendesak para pembesar untuk mencari inisiatif baru bagi memastikan pendapatan mereka adalah sentiasa lebih baik. Faktor pendapatan tersebut menjadi keutamaan pembesar sehingga mereka turut memikirkan bahawa sistem kerah dilihat sudah kurang efisien dan langkah mengupah tenaga buruh Cina boleh membantu menjadi penyumbang pendapatan mereka. Walaupun pada abad ini kemasukan orang Cina masih pada skala yang kecil namun penglibatan pemodal-pemodal Cina telah menampakkan hasil pengeluaran yang menguntungkan. Sementara itu, pada tahun 1864 Kedah berjaya meletakkan pengeluaran padi pada tahap yang baik apabila padi telah menjadi eksport utama ke Pulau Pinang. Misalnya, pada tahun ini Kedah telah menunjukkan rekod yang stabil setelah memperoleh pendapatan sebanyak $\$ 10,000$ dalam pengeksportan beras.

Seterusnya, sebelum 1909 ini Kedah telah melakukan penguasaan dalam pengeluaran padi dan dilihat menunjukkan prestasi yang sangat baik. Keadaan ini berlaku setelah pemerintah Kedah telah mula menjalinkan hubungan dengan pihak British di Pulau Pinang dan pedagang-pedagang Cina. Sultan telah mengambil langkah ini untuk memastikan kedudukan ekonomi negeri Kedah stabil di samping mencari peluang untuk menambahkan lagi kegiatan ekonomi yang lain. Oleh itu, pada tahun 1873 Kedah berusaha memperluaskan pengaruh dalam pengeluaran padi yang kemudiannya menjadi pengeksport utama kepada Pulau Pinang. Berdasarkan jadual yang disediakan menunjukkan setiap pelabuhan di Kedah yang berperanan dalam mengeksport hasil pengeluaran sumber di Kedah kepada Pulau Pinang khususnya pengeluaran padi dan beras yang mendominasi bagi setiap pelabuhan. ${ }^{9}$

Jadual 1: Hasil Eksport Pelabuhan Kedah ke Pulau Pinang, 1873

\begin{tabular}{|l|l|}
\hline \multicolumn{1}{|c|}{ Pelabuhan } & Hasil Keluaran \\
\hline Meraket & Kayu \\
\hline Lungoo & Damar, minyak damar dan rotan \\
\hline Setul & Lembu, beras dan padi \\
\hline Sanglang & Beras dan padi \\
\hline Perlis & Beras dan padi \\
\hline Kuala Kedah & Beras, padi dan lembu \\
\hline Jerlun & Padi dan beras \\
\hline Langkawi & Gam, padi dan beras \\
\hline Singkir & Kayu api \\
\hline Merbau & Kayu api \\
\hline Kuala Salah & Padi dan beras \\
\hline Kuala Muda & Padi dan beras \\
\hline Kulim & Bijih timah, rotan dan perak \\
\hline Baling & Bijih timah \\
\hline Bagan Samak & Padi \\
\hline
\end{tabular}


Sumber : J. M. Gulick, “ Kedah “ dalam JMBRAS, Vol. 58, 2, 1985, hlm. 115. Lihat juga Foziah bt Hat, Kedah Di bawah Kepimpinan Sultan Ahmad Tajuddin (II) Mukarram Shah (1854-1879), Latihan Ilmiah, Jabatan Sejarah, Fakulti Sains Kemasyarakatan Dan Kemanusiaan, Universiti Kebangsaan Malaysia, 1990/91, hlm. 86-87.

Menurut jadual di atas jelas menunjukkan pengeluaran padi dan beras telah menguasai pelabuhan-pelabuhan Kedah. Malah usaha giat yang dijalankan pemimpin telah menampakkan hasilnya yang baik apabila padi dan beras menjadi permintaan utama oleh Pulau Pinang. Daripada itu, dapat dibuktikan pada abad ke-19 ini Kedah telah melakukan eksport 7000 ton beras dan negeri khusus yang terlibat adalah Pulau Pinang. Justeru, interaksi pemerintah dengan orang Cina yang seterusnya telah membawa perubahan dalam corak pertanian padi di Kedah iaitu daripada sara diri kepada komersial. Ditambah pula ketika ini kawasan pertanian padi di Kedah didapati telah bertambah luas dengan terbinanya beberapa siri terusan umpamanya di daerah Kota Setar. ${ }^{10}$ Bermula abad ke-19 sehingga awal abad ke20, hubungan ekonomi yang terjalin antara pemerintah dan orang Cina telah menjadikan peranan petani Melayu semakin berkurangan. Pertanian secara tradisi masih kekal diteruskan oleh petani Melayu walaupun setelah penglibatan orang Cina. Kemasukan orang Cina ke Kedah dari tahun ke tahun telah memaksa orang Melayu akur dengan segala kegiatan ekonomi mereka yang lebih cekap.

Di sini, jelas pengeluaran padi menjadi kegiatan ekonomi yang sangat penting terhadap Kedah sebelum kedatangan British. Usaha-usaha yang dijalankan oleh pemerintah dan pembesar pula dilihat memberi impak positif terhadap pendapatan mereka dalam aspek pertanian padi bahkan bersifat negatif pula kepada para petani Melayu yang terpaksa menjadi orang kerahan para pemimpin mereka. Sementara itu, hubungan yang terjalin antara Kedah dan Pulau Pinang pula telah membuka sedikit peluang kepada para pedagang Cina untuk terlibat dalam ekonomi Kedah. Selain itu, ekoran pembukaan tanah pada abad ke-19 juga telah menjadi penyebab kemasukan beramai-ramai orang Cina dan India ke Kedah yang kemudiannya menyebabkan berlakunya pertambahan penduduk di Kedah. Di samping itu, terdapat beberapa orang Cina yang mempunyai peranan yang penting dalam ekonomi negeri Kedah dan mereka ini antara saudagar Cina yang memiliki hubungan baik dengan sultan Kedah. Antaranya, Choong Cheng Kean, Lim Boon How, dan Lim Lan Jak. Lim Lan Jak merupakan tauke yang berjaya dalam beberapa jenis pertanian termasuklah pertanian padi dan pertanian komersial seperti penanaman ubi kayu dan kopi di Kulim. Selain itu, mereka turut diberi konsesi pajak di Kedah yang merangkumi pajak padi dan beras di daerah Kota Setar. ${ }^{11}$ Sultan didapati telah menggunakan sistem hasil yang melibatkan mekanisme pengutipan hasil kerana dilihat lebih efektif. Dalam sistem ini telah diwujudkan sistem pajakan cukai yang kebanyakannya dikuasai oleh pemodal Cina. Tindakan sultan dalam menyediakan sistem ini telah menyebabkan orang Melayu ketinggalan dalam memperkembangkan kegiatan ekonomi mereka.

Pelaburan saudagar Cina di Kedah telah menyebabkan kaum tani Melayu mengalami kerugian. ${ }^{12}$ Para saudagar Cina ini berusaha mencari peluang untuk menguasai ekonomi orang Melayu sehinggalah pelabur Cina ini memberi tumpuan terhadap pertanian padi di

Kota Setar. ${ }^{13}$ Penguasaan orang Cina sikit demi sedikit telah membuka peluang munculnya ramai pengilang Cina dalam negeri yang telah memberi impak negatif kepada petani Melayu.

\section{Dominasi Pengilang Cina Dalam Pengeluaran Beras}

Penglibatan orang Cina dalam ekonomi negeri Kedah sememangnya telah berlaku sebelum campur tangan British lagi. Namun, selepas termaktubnya perjanjian Bangkok 1909, dasar 
keterbukaan British telah membuka peluang besar kepada orang Cina untuk berhijrah ke Kedah. ${ }^{14}$ Oleh itu, secara tidak langsung dasar liberal telah dijalankan dengan lebih meluas. Kedatangan saudagar Cina telah menyebabkan penguasaan ekonomi jatuh ke tangan mereka sehingga menyebabkan peluang petani Melayu untuk mengembangkan ekonomi mereka sangat tipis. Persaingan yang wujud terutama dalam pertanian padi jelas menampakkan kemunduran petani Melayu. Pada abad ke-20 didapati modal yang dikeluarkan oleh saudagar Cina Kedah telah membawa perubahan dalam ekonomi dan politik Kedah. ${ }^{15}$

Selanjutnya, pada abad ke-20 pembukaan tanah pertanian padi didapati semakin meluas di dataran Kedah. Pembukaan tanah ini juga disebabkan kesan kedatangan pelabur Cina yang telah menunjukkan perkembangan positif dalam membangunkan pertanian padi ini. Tanah-tanah yang diteroka adalah seluas 106000 ekar di lembah Kedah. Kemudian pada tahun 1918, penerokaan ini telah bertambah menjadi 220000 ekar. $^{16}$ Di sini jelas menunjukkan setelah campur tangan British, pertanian padi telah menjadi keutamaan ekonomi negeri pada abad tersebut. Perbincangan ini dapat dibuktikan berdasarkan jumlah kemasukan orang Cina di dataran Kedah melalui jumlah yang ditunjukkan dalam jadual di bawah.

\section{Jadual 2: Jumlah Penduduk Mengikut Kaum di Dataran Kedah, 1911}

\begin{tabular}{|l|l|l|l|}
\hline Daerah & Melayu & Cina & India \\
\hline Perlis & 25,618 & 3,200 & 400 \\
\hline Kubang Pasu & 25,106 & 840 & 423 \\
\hline Kota Star & 91,561 & 8,744 & 999 \\
\hline Yan & 14,061 & 744 & 53 \\
\hline Jumlah & 156,346 & 13,528 & 1,875 \\
\hline
\end{tabular}

Sumber: Afifudin Haji Omar, 'Penanaman Padi Di Kedah: Sejarah Pertanian Dalam Ekonomi Negeri Kedah’ dalam Alor Setar 250 Tahun, Kerajaan Kedah Darul Aman, 1990, hlm. 25.

Berdasarkan jadual tersebut, didapati ketiga-tiga kaum iaitu Melayu, Cina dan India tertumpu di daerah Kota Setar. Ketiga-tiga kaum ini mewakili 91,561 Melayu, 8,744 Cina dan 999 India. Jika dibandingkan dengan dataran daerah-daerah yang lain, Kota Setar menjadi tumpuan utama oleh ketiga-tiga kaum ini disebabkan Kota Setar merupakan daerah yang strategik dan merupakan pusat pentadbiran kerajaan Kedah. Kepesatan Kota Setar telah menarik minat pelbagai kaum untuk terlibat dalam menjalankan pelbagai kegiatan ekonomi, antaranya aktiviti pertanian padi, perladangan, dan perniagaan. Pada tahun 1910, orang Cina telah mula memberi tumpuan terhadap kegiatan penanaman padi ekoran dasar liberal British. Pelabur dan pengusaha Cina telah memberi tumpuan kepada pertanian ini dengan cara penggunaan peralatan yang lebih cekap dan moden. Misalnya, mereka ini telah menubuhkan kilang-kilang beras setelah memperoleh hasil pinjaman kewangan dari Pulau Pinang. Ini dapat dilihat pada tahun 1911 apabila berlaku pertambahan peniaga-peniaga Cina di Kedah yang mengusahakan pertanian padi. Orang Cina ketika itu menjadi pembeli padi yang penting dan kemudiannya membantu meningkatkan sektor ekonomi Kedah. Pada ketika ini terdapat 102 orang peniaga Cina yang menguruskan perniagaan padi di Kota Setar dan didapati jumlah ini lebih besar daripada peniaga Melayu. ${ }^{17}$ 
Perkembangan penduduk di Kedah berterusan ke tahun-tahun berikutnya yang kemudiannya telah menimbulkan pelbagai ketidakpuasan hati kepada petani Melayu terhadap peniaga Cina terutamanya dalam sektor pertanian padi. Pengilang Cina telah menunjukkan penguasaan mereka dalam sektor ini dengan mengambil beberapa peranan penting dalam perkembangan sektor tersebut. Selain itu, terdapat beberapa bentuk dominasi yang dilihat telah memberi impak terhadap petani Melayu.

\section{Pertumbuhan Kilang Beras Cina}

Sememangnya tidak dapat dinafikan bahawa dengan berkembangnya kilang-kilang beras di Kedah telah menyebabkan bertambahnya pengilang Cina. Peranan pengilang Cina dilihat merupakan pihak yang penting dalam mendapatkan hasil-hasil padi daripada petani Melayu. Oleh itu, dominasi pengilang Cina jelas berlaku dalam kehidupan petani Melayu yang semakin lama terus berada dalam kemiskinan. Pertumbuhan kilang beras yang banyak menunjukkan dominasi mereka terhadap proses pengeluaran padi dan beras. Jadual yang disediakan dapat menunjukkan jumlah kilang beras yang sudah dibina dan masih dalam pembinaan diterajui oleh orang Cina sehingga tahun $1938 .{ }^{18}$

Jadual 3: Senarai Kilang Beras di Kedah Yang Masih dalam Pembinaan, 1938

\begin{tabular}{|l|l|l|c|}
\hline $\begin{array}{l}\text { Masih Dalam } \\
\text { Pembinaan }\end{array}$ & Kawasan & Daerah & $\begin{array}{c}\text { Jumlah Keluaran } \\
\text { Padi (beg) }\end{array}$ \\
\hline Chin Guan Leong & 5 batu daripada A. Bukit & Kota Setar & 100 \\
\hline Hoe Seng & 2 batu daripada Pumpong & Kota Setar & 160 \\
\hline Ban Chuan Leong & Kubang Rotan & Kota Setar & 300 \\
\hline Ban Chuan Lee & Kubang Rotan & Kota Setar & 90 \\
\hline Ban Heng Bee & Seberang Perak & Kota Setar & 300 \\
\hline Ghee Seng & Bt. Besar 11 1/2 batu & Kota Setar & 220 \\
\hline Thean Peng & Tokai & Kota Setar & 200 \\
\hline Hup Soon Hong & Tokai & Kota Setar & 140 \\
\hline Hock Hoe Seng & Kuala Sala & Yen & 95 \\
\hline Lian Tiak R. M. \& Co. & Guar Chempedak & Yen & 90 \\
\hline Seng Lee & Kodiang & Kubang Pasu & 70 \\
\hline Seng Joo & Sungai Petani & Kuala Muda & 170 \\
\hline
\end{tabular}

Sumber : SUK.K, 3381 / 1357, Rice Mills in Kedah. Lihat juga, X. A. Wu, 'Chinese Family Business Network in the Making of a Malay State: Kedah and the Region c. 1882 - 1941', Faculty of Social and Behavioural Sciences, University of Amsterdam, 1999, hlm. 237-238.

Berdasarkan jadual tersebut menunjukkan jumlah kilang padi yang telah dibina oleh pemodal Cina mengikut daerah di Kedah. Kilang-kilang ini telah dibina di daerah Kota Setar dan Kubang Pasu. Pada akhir tahun 1938, sebanyak 12 buah kilang sudah dibina. Sehubungan itu, pertumbuhan kilang-kilang beras tersebut adalah selari dengan perkembangan kegiatan penanaman padi dan hasil padi yang diperoleh berkembang dengan baik. Dengan adanya kilang-kilang kecil mahupun kilang besar, pemprosesan padi didapati dapat dilakukan dengan lebih cepat. Malahan, penggunaan teknologi mesin dalam pemprosesan padi pula menjadi penyumbang yang besar dalam mempercepatkan proses pengeluaran hasil beras. Sebagai contoh dalam sehari sesebuah kilang beras dapat mengeluarkan padi dalam anggaran 20 
hingga 80 beg. Oleh itu tidak hairanlah jika Kedah dipenuhi dengan tauke Cina dan pengilang Cina yang sentiasa mencari peluang untuk menguasai sektor pengeluaran padi.

Kilang-kilang padi milik orang Cina banyak tertumpu di kawasan-kawasan seperti Kota Setar, Kubang Pasu, Yan dan Kuala Muda. Terdapat beberapa faktor yang menyebabkan Kota Setar menjadi antara kawasan tumpuan pemodal Cina terlibat dalam perusahaan kilang beras antaranya, faktor kesesuaian tanah yang luas untuk kegiatan penanaman padi. Selain itu, di Kota Setar pemodal Cina yang mengusahakan kilang mudah untuk memperoleh barang-barang keperluan kilang kerana terdapat banyak peniaga Cina yang telah menjalankan perniagaan di Kota Setar misalnya, perniagaan pasir, elektrik, perkakas-perkakas pertanian dan sebagainya. Kilang-kilang beras ini mengutamakan penggunaan mesin dalam memproses padi dan kaedah ini lebih cepat dan dapat mengurangkan tenaga kerja dalam kilang.

Secara logik, pertambahan kilang ini akan menambahkan lagi pengilang-pengilang padi Cina yang akan kerap melakukan pembelian padi murah daripada petani Melayu. Sementara itu, dapat dilihat jumlah beg beras yang terhasil dalam sehari didapati lebih banyak berbanding kilang-kilang yang sudah terbina lebih awal. Ini dapat dibuktikan apabila jumlah keluaran dalam sehari mencapai 300 beg beras bagi kilang Ban Heng Bee di Seberang Perak, Kota Setar. Manakala, pada awal tahun 1921, pembukaan kilang beras di Anak Bukit yang dikendalikan oleh Goh Soon Leong dan beliau sendiri turut berperanan dalam melantik ejen-ejen atau pengilang padi Cina di Kedah untuk melancarkan proses perolehan hasil padi. Di sini menunjukkan kelebihan yang dimiliki oleh tauke-tauke kilang apabila berkemampuan melantik ejen-ejen mereka sendiri dan diletakkan di kawasan-kawasan penanaman padi misalnya, Goh Soon Leong menempatkan ejennya di Jitra, Kodiang, Langgar, Simpang Empat, Ayer Hitam dan Sanglang. Ejen-ejen yang diletakkan di kawasan-kawasan ini berperanan mengawal proses jual beli padi.

Walau bagaimanapun, perkembangan kilang-kilang beras oleh orang Cina menyumbang pendapatan terhadap negeri namun telah memberi impak terhadap petani Melayu. Kesusahan mereka didapati berterusan seiring dengan pertambahan kilang beras yang dimiliki orang Cina. Akibat daripada itu, orang Melayu cuba menunjukkan persaingan dengan mengambil langkah membangunkan kilang-kilang beras orang Melayu. Oleh itu, pada tahun 1938 dan 1940, dapat dilihat kewujudan kilang-kilang beras orang Melayu. ${ }^{19}$

Jadual 5: Pemilikan Kilang Beras Orang Melayu, 1938

\begin{tabular}{|c|c|c|c|}
\hline Nama Kilang & Kawasan & Daerah & $\begin{array}{c}\text { Kapasiti Beg Beras } \\
(\mathbf{1 2} \text { jam })\end{array}$ \\
\hline Haji Abu Bakar \&Son & Batu 5 1/2 Langgar & Kota Setar & 16 \\
\hline Mohamed Saad & Batu 13 Jitra & Kubang Pasu & Kilang Dalam Pembinaan \\
\hline $\begin{array}{c}\text { Haji Jaafar bin } \\
\text { H.Salleh Co-operative }\end{array}$ & Tikam Batu & Kuala Muda & 16 \\
\hline Mohamed Sajak & Pulai & Baling & 22 \\
\hline Haji Yaacob bin Ludin & Kupang & Baling & 22 \\
\hline
\end{tabular}

Sumber: SUK. K, 3381/1357, Rice Mill in Kedah. Lihat juga, X. A. Wu, 'Chinese Family Business Network in the Making of a Malay State: Kedah and the Region c. 1882 - 1941', Faculty of Social and Behavioural Sciences, University of Amsterdam, 1999. 
Jadual 6: Pemilikan Kilang Padi Kecil Melayu, 1940

\begin{tabular}{|l|c|c|}
\hline \multicolumn{1}{|c|}{ Nama pemilik } & Kawasan & Kapasiti Beg Beras (12 Jam) \\
\hline Hashim bin Awang & Yan & 18 \\
\hline Awang b. Haji Jassin & Yan & 15 \\
\hline Haji Ahmed b. Ismail & Baling & 12 \\
\hline Che Awang b. Abu Bakar & Baling & 8 \\
\hline Md. Omar b. Sheikh Akbar & Baling & 9 \\
\hline Haji Yaacob b. Haji Noordin & Baling & 4 \\
\hline TunkuDaud b. TunkuHaider & Kuala Muda & 7 \\
\hline $\begin{array}{l}\text { Haji Abdul Warit b. Haji Md. } \\
\text { Darus }\end{array}$ & Kuala Muda & 24 \\
\hline Md. Taib b. Haji Man & Kuala Muda & 25 \\
\hline Ahmed b. Haji Abdullah & Kuala Muda & 54 \\
\hline Shafie b. Abdul Rahman & Sik & 53 \\
\hline $\begin{array}{l}\text { Syed Hussein b. Syed Md. } \\
\text { Almakhthir }\end{array}$ & Sik & \\
\hline
\end{tabular}

Sumber: X. A. Wu, 'Chinese Family Business Network in the Making of a Malay State: Kedah and the Region c. 1882 - 194', Faculty of Social and Behavioural Sciences, University of Amsterdam, 1999, hlm. 239.

Berdasarkan jadual 5 dan 6 menunjukkan kilang-kilang yang dimiliki oleh orang Melayu pada penghujung tahun 1938 dan 1940. Disebabkan impak perkembangan kilang beras yang didominasi oleh pengilang Cina telah menjadi faktor kepada orang Melayu untuk turut membangunkan kilang beras sendiri. Kilang-kilang yang dibangunkan ini juga adalah atas usaha pihak kerajaan untuk membantu petani Melayu dan orang Melayu yang berkelayakan menjalankan operasi pemprosesan beras. ${ }^{20}$ Satu faktor yang menyebabkan campur tangan kerajaan dalam pembinaan kilang-kilang beras untuk orang Melayu ialah disebabkan oleh aktiviti hutang yang berleluasa berlaku dalam kalangan petani Melayu. Senario tersebut dipersetujui oleh Pegawai Pertanian Kedah iaitu TunkuYaacob yang berpendapat bahawa kerajaan telah berusaha membantu petani Melayu, namun pengaruh pemodal Cina dalam kemajuan perkilangan padi di Kedah telah menyukarkan lagi kehidupan petani Melayu. Sementara itu kebergantungan dan hutang budi kepada orang Cina turut menyebabkan petani Melayu terus berada dalam kemiskinan.

Kesusahan petani Melayu kesan dominasi pengilang Cina tidak sekadar berlaku di sesetengah mukim, tetapi kesannya meluas di seluruh negeri Kedah. Petani Melayu terpaksa berterusan bergantung kepada pengilang Cina sehingga membebankan mereka. Misalnya, terpaksa menjual hasil padi dengan harga yang murah dalam keadaan kesempitan bekalan makanan. Dalam hal ini juga petani Melayu akan menerima musibah yang lebih sukar sekiranya tanaman padi yang diusahakan tidak menjadi dan hutang-hutang yang ditanggung terus bertambah. Sebagai contoh, pada tahun 1930 di daerah Padang Lumat iaitu di Mukim Sala Besar hasil padinya tidak menjadi. Situasi ini menjadi kerisauan mereka apabila tiada hasil yang cukup untuk diserahkan kepada pengilang Cina dan para petani ini tidak mahu harta yang mereka miliki, tergadai kepada orang Cina. Kes ini telah diajukan kepada pihak kerajaan bagi memohon bantuan yang bersesuaian dalam menyelesaikan masalah tersebut. ${ }^{21}$

Di sini jelas menunjukkan kedatangan pemodal Cina dilihat sebagai pencetus perubahan ekonomi di Kedah terutama dalam sektor pertanian padi. Sementara itu, pemodalpemodal pula sentiasa melihat peluang besar yang memberi keuntungan lumayan misalnya 
dengan pembinaan kilang-kilang beras akan meningkatkan skala pengeluaran yang lebih besar. Dengan terbinanya kilang-kilang beras ini, jelas terbukti kemajuan yang berlaku dalam negeri Kedah setelah padi-padi ini dapat diproses dengan lebih cekap dan cepat. Pengeluaran beras yang banyak juga jelas membuktikan keupayaan Kedah dalam melakukan kegiatan eksport ke negara-negara luar. Pengeksportan padi dan beras dari Kedah ini juga telah diperluaskan sehingga ke Negeri-Negeri Selat (NNS) dan Negeri-Negeri Melayu Bersekutu $(\mathrm{NNMB}){ }^{22}$

\section{'Creditor' Utama dalam Penanaman Padi}

Pengilang padi Cina di Kedah berperanan sebagai pembekal barangan runcit dengan menjadi 'creditor' yang utama kepada petani Melayu. Oleh itu, golongan ini akan menjalankan urusan jual beli secara hutang dan kegiatan penjualan ini kerap berlaku pada musim penanaman padi serta ketika padi membesar. ${ }^{23}$ Kemudian apabila tiba musim menuai, petani Melayu akan menyelesaikan hutang dengan cara menjual semula padi mereka kepada pengilang Cina. Namun, harga jualan pula akan ditetapkan oleh pengilang dan ternyata penetapan harga untuk petani Melayu dibayar dengan harga yang sangat murah.

Perkembangan peranan pengilang Cina sebagai 'creditor', telah menyebabkan petani Melayu muncul sebagai kelompok yang berada dalam kemiskinan. Pada peringkat awalnya, petani Melayu telah memberi kepercayaan kepada pengilang Cina untuk memasarkan hasil padi mereka. Namun, didapati telah wujud satu masalah apabila pengilang Cina telah menunjukkan helah mereka dengan mengikat petani Melayu melalui hutang. Dapat dinyatakan bahawa pengilang Cina telah mewujudkan pergantungan berterusan petani Melayu kepada pengilang Cina.

Berikutan itu, kaedah hutang yang dibuat oleh pengilang Cina terhadap petani Melayu dikenali sebagai padi kunca ${ }^{24}$ dan kaedah ini jelas mewujudkan berlakunya penindasan yang telah merisaukan ramai pihak. Ditambah pula pada tahun 1930, dengan tindakan tauke-tauke kilang beras di Kedah yang telah mencapai kata sepakat untuk menetapkan harga baru bagi setiap pembelian padi daripada petani Melayu. Menurut mereka setiap pembelian padi tidak boleh melebihi $\$ 4$ pada satu kunca yang mana sebelum ini berharga $\$ 9$. Tindakan penurunan harga padi ini telah diketahui oleh ketua penghulu Pendang dan Padang Pusing dan dinyatakan keadaan ini telah memberikan masalah kepada petani Melayu kerana kebanyakan mereka bergantung hidup terhadap bantuan pengilang padi Cina. ${ }^{25}$

Pengilang Cina pula akan menawarkan pinjaman kewangan serta barang-barangan yang diperlukan dalam kegiatan penanaman padi. Oleh itu, mereka menyediakan perkhidmatan pinjaman wang untuk memudahkan para petani; namun pada masa yang sama, ia telah membebankan petani Melayu apabila terpaksa menyediakan ganjaran yang baik untuk diberikan kepada pihak pengilang Cina. Pengilang Cina juga telah meletakkan syarat di mana sekiranya petani Melayu ingin membuat pinjaman kewangan, mereka harus menjual hasil tanaman kepada pengilang Cina dengan harga yang murah. Umpamanya, terdapat satu kes yang berlaku di Kota Setar iaitu di Mukim Langgar dan Limbong pada tahun 1930. Dalam kes ini, penghulu Kota Setar telah menghantar surat aduan kepada Tuan Ketua Penghulu daerah Kota Setar bagi menyampaikan luahan petani Melayu mengenai perbuatan pengilang Cina. Menurut mereka, sekiranya petani Melayu mempunyai duit barulah mereka akan menjual benih padi dan jika petani Melayu ingin berhutang pula, mereka perlu menyerahkan lesen kerbau dan lembu serta surat tanah. Petani-petani tersebut tidak mahu perkara ini berlanjutan kerana situasi tersebut akan merugikan mereka. Oleh itu, sebagai langkah terbaik, petani-petani Melayu terpaksa memohon bantuan kewangan daripada pihak kerajaan bagi membantu mendapatkan benih-benih padi. ${ }^{26}$

Tambahan pula pada tahun 1930, didapati terdapat 39 mukim di daerah Kota Setar yang mengusahakan sawah padi dan semua mukim ini terlibat dalam penjualan padi kepada 
pengilang Cina. Walaupun semua mukim tersebut menjalankan penanaman padi, tetapi tidak semua mukim menjanjikan keuntungan hasil yang lumayan. Berdasarkan laporan tahun 1930, hanya 13 mukim sahaja yang mendapat keuntungan setelah penjualan padi kepada pengilang Cina. Manakala 26 mukim lagi didapati telah mengalami kerugian. ${ }^{27}$

Sistem padi kuncha ini didapati telah menindas orang Melayu. Dalam hal ini, pengilang Cina didapati telah mengeksploitasi ekonomi mereka. Keadaan ini jelas dapat dilihat telah berlaku sejak abad ke-19 yang kemudiannya berlanjutan sehingga abad ke-20 iaitu selepas campur tangan British. Orang Cina dilihat begitu mudah memperoleh tanah petani Melayu. Contohnya, orang Cina memperoleh tanah petani Melayu dengan lelongan tanah disebabkan tidak mampu melangsaikan hutang. Dalam hal ini, urusan lelongan dilakukan oleh pihak kerajaan setelah menerima aduan daripada pihak-pihak tertentu. Misalnya kes yang melibatkan petani iaitu Mohamed Bin Mohamed Hasan yang terpaksa memindahkan hak milik tanahnya di Mukim Tajar dalam daerah Kota Setar kepada Ooi Wee Kiok untuk menjelaskan hutangnya. ${ }^{28}$

Dalam soal pinjaman ini, pengilang Cina yang mempunyai hubungan dengan peruncit Cina telah menyediakan kemudahan kredit berbentuk wang tunai. Perolehan tunai ini bertujuan untuk membeli baja, racun serangga dan kelengkapan lain yang diperlukan oleh orang Melayu bagi melancarkan kegiatan penanaman padi. Di samping itu, petani Melayu turut terlibat dalam hutang jual janji. Hutang jual janji ini melibatkan hal tanah. Petani Melayu yang didapati mempunyai hutang dengan pengilang Cina terpaksa mencagarkan geran tanah mereka sekiranya tidak dapat menjelaskan hutang tersebut.

\section{Dominasi Pengilang Cina dalam Teknologi dan Pengangkutan}

Padi yang dibeli daripada petani-petani Melayu oleh pengilang Cina kemudiannya dibawa ke Pulau Pinang untuk diproses dengan menggunakan kaedah yang lebih moden. Langkah tersebut dilaksanakan oleh pengilang Cina disebabkan petani Melayu mengalami kekurangan peralatan yang lebih cekap untuk memproses padi. Oleh itu hasil padi yang dituai oleh petani Melayu dengan mudah sahaja dimonopoli oleh pengilang Cina. Kecekapan pengilang Cina dalam aspek pemprosesan padi ini lebih cekap apabila mereka menggunakan mesin kuasa wap sebagaimana kilang padi yang telah dibangunkan di Mukim Kubang Rotan pada tahun 1913. Kilang ini dimiliki oleh tauke Lim Gan yang telah berjaya mengatasi kegiatan petani Melayu. Perkembangan kilang padi berkuasa wap yang dimiliki oleh orang Cina jelas menampakkan kemunduran petani Melayu dalam pemprosesan padi. Ini ditambah lagi dengan kewujudan kilang padi berkuasa wap di Kedah pada tahun 1919 iaitu, Ban Hin Mill dan Kubang Rotan Mill yang bertempat di Alor Setar dan JooHin Mill di Kuala Muda. ${ }^{29}$

Justeru, dominasi pengilang Cina dapat dilihat dalam aspek pengangkutan di mana sangat penting bagi melancarkan sesebuah perniagaan. Oleh itu, penglibatan mereka turut mempengaruhi sistem pengangkutan moden yang digunakan dalam pemasaran padi. Pengenalan sistem pengangkutan padi tersebut dilihat telah menyebabkan petani Melayu berterusan tertindas. Aspek kekurangan yang dihadapi telah mengheret petani Melayu ke jalan kemiskinan walaupun telah mengeluarkan hasil padi dengan tulang empat kerat mereka namun diakhirnya, hasil atau keuntungan sebenar dimiliki oleh pengilang Cina.

Tambahan pula, kesusahan dan kesukaran petani Melayu dalam memasarkan hasil padi di bandar telah memberi peluang kepada pengilang Cina mahupun pekedai Cina untuk menindas petani Melayu. Ini disebabkan, untuk menjalankan kegiatan pemasaran di bandar memerlukan pengangkutan yang sesuai dan memastikan hasil padi selamat sampai tanpa sebarang masalah. Oleh itu, faktor pengangkutan ini memberi kesukaran kepada petani Melayu kerana mereka hanya memiliki kerbau, sampan, basikal yang sering digunakan sebagai pengangkutan utama. Dengan menggunakan pengangkutan ini, petani Melayu semestinya tidak dapat membawa hasil tuaian padi dalam kuantiti yang banyak ke bandar dan 
apa yang menyedihkan di sini, kesukaran tersebut telah menyebabkan petani Melayu mengalami kerugian kerana memperoleh keuntungan yang kecil. ${ }^{30}$

Suasana ini berbeza pula dengan kilang-kilang padi yang besar. Kebiasaannya, kilangkilang tersebut memiliki pengangkutan sendiri iaitu lori dan bot kargo dan sememangnya akan memberi kemudahan dan keuntungan yang banyak kepada pemilik kilang. ${ }^{31}$ Pengangkutan seperti lori dan bot kargo ini berkemampuan menampung kuantiti padi yang banyak seterusnya dibawa ke kilang untuk diproses. Selain itu, bagi kilang-kilang padi yang berskala kecil pula, mereka turut memiliki pengangkutan mengangkut padi sendiri, misalnya bot-bot kecil dan kereta. Manakala, ejen-ejen pengilang padi seperti peruncit atau pekedai pula memiliki kedai yang berkeluasan besar untuk menampung penyimpanan padi dan juga mempunyai kenderaan mengangkut padi seperti lori.

Meskipun petani Melayu telah berusaha memasarkan namun diakhirnya mereka terpaksa berputus asa jugadan mengambil keputusan untuk menyerahkan hasil padi kepada pengilang Cina yang berhampiran disebabkan masalah pengangkutan. Selain itu, terdapat kaedah lain yang cuba diusahakan petani Melayu. Sebagai contoh, mereka menggunakan sistem pengangkutan air untuk membawa hasil padi ke tepi jalan dan menunggu lori bagi tujuan memungut padi untuk dibawa langsung ke kilang.

\section{Dominasi Pemasaran}

Situasi ini amat jelas dalam sektor pertanian padi apabila orang Cina lebih maju dalam mendirikan kilang-kilang beras di Kedah. Kilang-kilang yang didirikan pula kebanyakannya tertumpu di kawasan bandar yang mempunyai pelbagai kemudahan, umpamanya Alor Setar ini merupakan lokasi tumpuan perniagaan orang Cina. Kekurangan dalam kemahiran pemasaran menyebabkan petani Melayu hanya memfokuskan dalam kegiatan pengeluaran padi sahaja manakala pengilang Cina dengan mudahnya mengambil peluang mengembangkan lagi kegiatan mereka dengan melakukan dominasi pemasaran beras.Walaupun dengan terdapatnya pengilang Cina yang berperanan memasarkan segala hasil tuai, namun hal ini tetap menyumbang masalah kepada petani Melayu. Pengilang Cina berperanan dalam mengikat petani Melayu serta mewujudkan pergantungan berterusan yang membawa petani Melayu hidup dalam kemiskinan. ${ }^{32}$

Interaksi pemasaran padi Cina di Kedah didapati berkembang dengan baik. Rangkaian kilang-kilang beras yang ditubuhkan menunjukkan perkembangan yang positif. Selain itu, dapat dinyatakan bahawa kemakmuran pengilang Cina di Kedah juga disebabkan aktiviti berhutang petani Melayu. Oleh itu, interaksi aliran pemasaran padi di Kedah adalah jelas berada di tangan pemodal dan pengilang Cina yang berperanan penting dalam soal perolehan padi dan pemasaran padi dan beras. Oleh itu, struktur aliran pemasaran ini dapat dijelaskan berdasarkan Carta 1.

Berdasarkan carta aliran berkenaan dapat dilihat aliran pengeluaran padi dan beras daripada petani kepada pengguna dalam negeri Kedah. Aliran pengeluaran padi dan beras berlaku dalam tujuh tahap yang melibatkan pesawah padi, pekedai atau pembeli, ejen pengilang padi, kilang, saudagar borong, peruncit dan pengguna awam. Proses pembelian dan penjualan di Kedah dijalankan tanpa campur tangan yang meluas daripada pihak kerajaan. Perniagaan beras dikuasai oleh syarikat persendirian melalui permintaan pasaran. ${ }^{33}$ Penyelarasan sistem pemasaran ini adalah untuk memastikan pengaliran beras berjalan dengan lancar. Ini disebabkan kebanyakan kilang beras di Kedah dimiliki oleh orang Cina terutamanya daripada kelompok Hokkien dan Kheks (Hakka). 


\section{Carta 1: Pemasaran Padi dan Beras di Kedah Sebelum 1941}

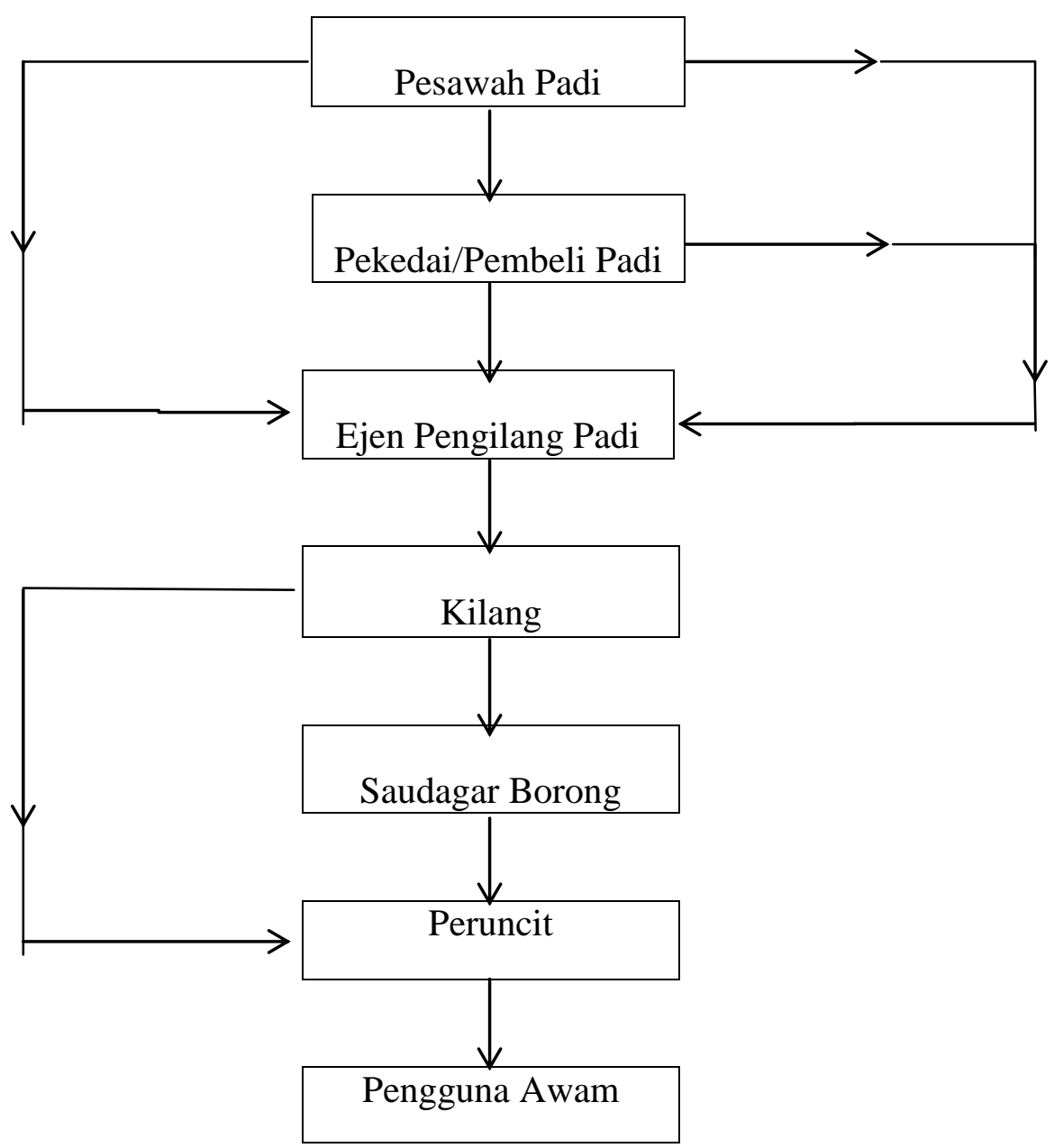

Sumber:Lee Say Lee, 'A Study of the Rice Trade in Kedah Before and During Japanese Occupation', Journal of the Malaysia Historical Society, No.24, Kuala Lumpur, 1981, hlm. 109.

Jika dilihat carta aliran di atas, punca utama pengeluaran padi dan beras terletak pada petani Melayu. Mereka memberi tumpuan dalam kegiatan penanaman padi namun selepas padi-padi mereka dituai, padi akan dibeli oleh beberapa pihak antaranya pekedai-pekedai dan pengilang Cina yang kemudiannya akan dihantar ke kilang utama untuk diproses. Dalam aspek pembelian padi ini, pekedai atau tauke kedai runcit di kampung-kampung berperanan untuk membeli padi petani Melayu bertujuan untuk memudahkan pemasaran pengeluaran padi. Walau bagaimanapun, disebabkan kekurangan tempat penyimpanan padi dan tiada pengangkutan untuk menghantar padi ke kilang, ia menjadi suatu masalah kepada petani Melayu. Justeru, keadaan tersebut telah menyebabkan petani Melayu terpaksa mengambil langkah mudah dengan menjual kepada peruncit kampung dan pengilang Cina. Pengilang Cina merupakan individu penting yang juga mempunyai hubungan perniagaan dengan tauke kedai runcit di kampung- kampung Melayu. Kebiasaannya, tauke-tauke runcit ini akan melakukan pembungkusan padi dalam bentuk beg dan menyimpan di belakang kedai sehingga pengilang Cina datang untuk mengambil hasil padi tersebut. ${ }^{34}$

Dalam aliran pengeluaran padi dan beras, kilang padi merupakan institusi pengeluaran yang paling penting sebelum ia dapat di pasarkan kepada pemborong dan seterusnya 
pengguna awam. Dalam konteks ini, peranan pengilang Cina dilihat sangat penting dalam mendapatkan bekalan padi daripada petani Melayu. Tambahan pula, jumlah orang Cina yang terlibat sebagai pengilang padi sememangnya besar. Misalnya pada tahun 1911 sudah terdapat 119 orang Cina yang memiliki lesen pembelian padi. ${ }^{35}$

Tahap seterusnya adalah di peringkat saudagar borong yang merupakan pihak yang mendapatkan bekalan beras secara pukal daripada pengilang. Saudagar borong ini juga merupakan antara pihak yang penting dalam saluran agihan beras kerana mereka adalah pihak yang mempunyai hubungan dengan ramai peruncit. Walaupun begitu, sebagai pemborong beras, mereka diharuskan untuk memperoleh lesen dan disyaratkan untuk mengikut segala peraturan untuk menjadi pemborong beras. Sebagai contoh, pada tahun 1919 telah dikeluarkan peraturan dan panduan untuk pemborong beras. ${ }^{36}$

1) Pemborong beras tidak boleh menjual beras kepada peruncit tanpa perintah bertulis daripada pegawai kawalan makanan.

2) Tidak boleh menjual dalam kuantiti kecil iaitu dalam gantang dan kurang daripada satu beg.

3) Peniaga borong hendaklah menyimpan dan mendaftar butiran-butiran mengenai tempat yang akan dibekalkan beras dan bilangan kuli (peruncit) yang terlibat.

4) Beras yang dipesan oleh peruncit mestilah direkodkan secara bertulis kemudiannya ditandatangani oleh majikan atau pengurus.

5) Pendaftaran mestilah disimpan di dalam bahasa Inggeris

6) Mereka yang sudah didaftar perlu dibawa ke pejabat ejen kawalan makanan setiap kali ada permintaan beras.

7) Setiap pemborong beras hendaklah menyediakan buku resit yang akan dikeluarkan apabila menerima pembayaran yang diterima daripada hasil jualan beras dan butirbutir mengenai amaun dan destinasi beras yang dijual oleh setiap peruncit.

Dalam pada itu, peruncit beras ini bukan sahaja dalam kalangan orang Cina, malah terdapat ramai juga orang Melayu yang menjadi orang tengah atau peruncit beras. Mereka yang terlibat ini antara yang telah memperoleh lesen untuk memasarkan beras di kawasan tertentu. Walau bagaimanapun, dalam aktiviti penjualan beras, peruncit memperoleh bekalan beras daripada syarikat beras tertentu yang kebanyakannya dimiliki oleh orang Cina. Misalnya pada tahun 1919, sebuah syarikat beras iaitu Hock Kee \& Co menjadi pembekal dan pemborong beras di Kulim. Terdapat beberapa peruncit yang berperanan dalam melakukan penjualan beras kepada penduduk. Antara peruncit yang terlibat dalam proses pengagihan beras kepada pengguna ialah seperti Ahat bin Asan, Haji Hamid, Ban Ho Tong, Lim Ah Too dan Haji Mun bin Salleh. Para peruncit ini akan diberikan beberapa kampit berdasarkan anggaran jumlah penduduk di sesebuah kawasan itu. Namun, pengedaran beras kepada peruncit ini, kebiasaannya adalah dalam jumlah kuantiti yang sama contohnya sebanyak 300 kampit beras. $^{37}$

Pada masa yang sama, syarikat beras yang terbabit dalam pembekalan beras kepada peruncit secara langsung turut dipantau pihak kerajaan. Ini disebabkan dalam aspek pengedaran serta pemasaran, pelbagai masalah telah timbul. Sebagai contoh, berlaku ketidakseimbangan pengagihan beras kepada para peruncit akibat tindakan pihak pemborong yang tidak bertanggungjawab. Mereka bersikap "pilih kasih" terhadap para peruncit yang berlainan bangsa. Keadaan ini dapat dilihat dalam kes yang di laporkan oleh peniaga beras dari Kulim yang menyuarakan ketidakpuasan hati terhadap pemborong beras iaitu Hock Kee \& Co yang melakukan proses agihan beras secara tidak adil. Misalnya, peruncit Melayu 
dalam kes tersebut dinyatakan hanya diberi sebanyak 160 beg beras manakala peruncit Cina memperoleh sebanyak 300 beg beras.

Akibat pengagihan beg beras yang tidak sama rata, telah memberi kesan negatif terhadap pengguna khususnya orang Melayu apabila mereka terpaksa bersaing dan berebut untuk membeli keperluan itu.

\section{Penubuhan Persatuan Pengilang Beras}

Kesan perkembangan pertanian padi di Kedah telah mendorong pelabur Cina mengambil langkah untuk menubuhkan persatuan yang memberi manfaat kepada mereka. Persatuan tersebut adalah "Persatuan Pengilang Beras dan Peniaga Padi". Penubuhan persatuan ini telah dilaporkan oleh pendaftar persatuan, Sungai Petani pada tahun 1931. Berdasarkan UndangUndang Persatuan 1928, penubuhan persatuan ini telah diluluskan dan didaftarkan di bawah Seksyen 6 Undang-undang Persatuan 1928 yang berkuat kuasa mulai 21 Disember $1931 .^{38}$ Dengan penubuhan persatuan ini semua pengusaha beras dan padi akan diletakkan di bawah satu persatuan. Terdapat beberapa objektif yang digariskan bagi memastikan ahli-ahli persatuan mendapat kebaikan, antaranya:

1) Setiap ahli akan mempelajari dan memperoleh ilmu penyelidikan berkaitan pasaran beras dan padi.

2) Untuk tujuan promosi dan memupuk hubungan baik sesama ahli.

3) Untuk merancang bagi memperoleh keberkesanan antara ahli dan bukannya monopoli secara individu.

4) Untuk memastikan keberkesanan penghantaran telegram dan surat berkaitan pasaran padi dan beras bagi kemudahan ahli.

Ahli persatuan ini terdiri dalam kalangan pengilang beras, penyimpan padi, dan peniaga padi. Oleh itu, peranan mereka juga berbeza dalam hal perniagaan padi dan beras. Antara pemilikpemilik kilang beras yang terlibat adalah seperti yang disenaraikan dalam jadual 7.

Jadual 7: Ahli Tertinggi Persatuan Pengilang Beras dan Peniaga Padi, 1931

\begin{tabular}{|l|l|l|}
\hline \multicolumn{1}{|c|}{ Pemilik } & \multicolumn{1}{c|}{ Kilang } & \multicolumn{1}{c|}{ Tempat } \\
\hline Lim EngSwee & Thean Peng Rice Mill & Tokai \\
\hline Tan Eng Soo & Ban Seng Hin Rice Mill & Kota Sarang Semut \\
\hline Chng Kong Hooi & Thean Seng Rice Mill & Alor Setar \\
\hline Oh Boon Soo & Ban Heng Bee Rice Mill & Alor Setar \\
\hline Teoh Kooi Ewe & Kong Soon Eng Rice Mill & Simpang Empat Kangkong \\
\hline Ooi Lay Poh & Hup Soon Hong Rice Mill & Tokai \\
\hline Tan Boon Hock & Chip Seng Rice Mill & Sungai Korok \\
\hline Tan Cheok Sim & JooHin Rice Mill & Kota Kuala Muda \\
\hline Ooi Hoe Sooi & Ban Chuan Leong Rice Mill & Kubang Rotan \\
\hline Tan ChekKooi & Hoe Seng Rice Mill & Pumpong, Alor Merah \\
\hline
\end{tabular}

Sumber: SUK. K 2544/1350, Registration of 'The Rice Millers and Padi Dealers Association', yang bertarikh 21 Disember 1931. 
Jadual 7 menunjukkan persatuan perniagaan yang dimiliki oleh orang Cina di Kedah yang ditubuhkan pada tahun 1931. Penubuhan persatuan ini melibatkan tauke-tauke kilang beras dan para peniaga padi yang menjadi pihak terpenting dalam pemasaran padi dan beras. Tujuan penubuhan persatuan ini ialah untuk mewujudkan hubungan permuafakatan dalam kalangan ahli mereka. Strategi padi kuncha atau sistem hutang yang dikenakan terhadap petani Melayu telah memberikan keuntungan yang besar sehingga telah membolehkan mereka memperoleh sejumlah 1,500 ekar tanah sawah. Sejajar dengan itu, mereka telah mengambil langkah dengan membangunkan kilang-kilang beras di kawasan yang strategik, misalnya di kawasan Kota Setar. Penyatuan pengilang dan peniaga padi dalam bentuk sebuah persatuan adalah sebagai langkah mengaut keuntungan. Dalam masa yang sama, aspek pengawalan terhadap harga padi juga menjadi objektif utama persatuan ini. Misalnya pada tahun 1930, dalam kes yang berlaku di Pendang, tauke-tauke kilang beras telah mencapai kata sepakat untuk menetapkan harga baru bagi setiap pembelian padi petani Melayu. Menurut mereka setiap pembelian padi tidak boleh melebihi $\$ 4$ bagi satu kunca yang mana sebelum ini berharga $\$ 9 .{ }^{39}$ Dengan tertubuhnya persatuan ini, tauke-tauke kilang beras dan peniaga padi mempunyai pengaruh yang kuat dan meluas dalam sektor ini. Namun keadaan ini memberi impak kepada petani Melayu kerana mereka terpaksa menanggung kerugian setiap kali berurusan dengan pengilang Cina. ${ }^{40}$

Penubuhan persatuan ini telah mendapat sokongan baik Pulau Pinang yang mempunyai hubungan ekonomi dengan Kedah sejak sebelum campur tangan British lagi. Dengan itu, setiap kilang beras yang dibina di Kedah sebenarnya mempunyai saling kaitan dengan Pulau Pinang. Misalnya dalam soal modal dan pemberian pinjaman kewangan kepada pelabur-pelabur yang terlibat dalam pembukaan kilang-kilang tersebut.Selain itu, dengan wujudnya persatuan ini penguasaan pengilang Cina dalam sektor pengeluaran padi membolehkan mereka berada dalam keadaan yang selesa apabila berjaya menyatukan semua peniaga Cina. Jalinan yang dilakukan tersebut juga akan memudahkan mereka untuk menyalurkan segala perubahan yang berlaku terutamanya berkaitan dengan penetapan harga padi dan beras.

\section{Kesimpulan}

Kebanjiran pemodal Cina di Kedah yang berlaku secara berperingkat secara tidak langsung telah membentuk corak ekonomi yang lebih moden dan cekap berbanding ekonomi orang Melayu yang masih berbentuk tradisional. Pemodal-pemodal Cina yang terlibat dalam sektor pertanian padi dilihat sentiasa mencari peluang yang lebih baik dengan bermatlamat mengaut keuntungan dengan lebih cepat dan besar. Namun begitu, peranan mereka dalam sektor ini didapati meninggalkan kesan negatif terhadap petani Melayu yang dikelilingi dengan hutang sehingga mewujudkan kebergantungan secara berterusan. Maka tidak hairanlah, pertambahan kilang padi tahun demi tahun dan lambakan pengilang Cina di setiap kawasan pertanian dilihat begitu memberangsangkan. Ini menyebabkan petani Melayu semakin dihimpit kemiskinan akibat dominasi mereka.

Justeru, dalam aspek penguasaan pengeluaran padi dan beras di Kedah jelas memperlihatkan berlakunya peralihan yang pada peringkat awal dikuasai oleh pembesar Melayu tetapi kemudiannya berpindah ke tangan orang Cina. Peralihan tersebut sememangnya begitu drastik setelah campur tangan British. Peralihan itu telah menyebabkan lambakan pengilang Cina yang sentiasa mencengkam kehidupan petani Melayu yang berada dalam kemiskinan. Dominasi pengilang Cina misalnya telah melahirkan sistem padi kuncha yang secara langsung telah menjerat petani Melayu. 
Nota

${ }^{1}$ Afifuddin Hj. Omar, Pembangunan Ekonomi Kaum Tani (Suatu Kajian Ekonomi - Politik di Wilayah Muda), diterjemahkan oleh, Daud Baharum, Kuala Lumpur, Dewan Bahasa dan Pustaka,1986, hlm. 51.

${ }^{2}$ R. O. Winstedt, The Malays A Cultural History, London: Routledge \& Kegan Paul Ltd, 1961, hlm. 125.

${ }^{3}$ R. Bonney, Kedah, 1771-1821: The Search for Security and Independence, Kuala Lumpur: Oxford University Press, 1971, hlm. 6.

${ }^{4}$ Kobkua Suwannanthat-Pian, "Sultan Ahmad Tajuddin Mukarram Shah" dalam Malaysia Dari Segi Sejarah, Bil. 17, 1989, hlm. 69.

${ }^{5}$ Sharom Ahmat, 'Political Structure of the State of Kedah', dalam Kedah Dari Segi Sejarah, Jilid 8, bil 1, 1979, hlm. 97.

${ }^{6}$ R. O. Winstedt, Kedah Laws, JMBRAS. Vo. IV, Part 11, 1928, hlm. 8.

7 Ampun kurnia merupakan satu anugerah yang khususnya terletak pada kuasa Sultan dalam melakukan pemberian tersebut dan sebagai sumber pendapatan tambahan. Ampun kurnia juga merupakan sumber pendapatan seseorang pembesar yang mana Sultan berkuasa mengurniakan seseorang itu terhadap sesiapa yang baginda kehendaki. Misalnya, ampun kurnia berbentuk tanah, wang, hak mengutip cukai dan sebagainya. Sementara itu, ampun kurnia juga dinyatakan salah satu taktik Sultan dalam melakukan tarikan atau memastikan para pembesar terus menunjukkan kesetiaan dengan anugerah atau hadiah dalam bentuk habuan ekonomi. Melalui ampun kurnia ini juga Sultan tidak mahu para pembesarnya lebih kaya daripada baginda. Oleh itu, setiap pemberian tersebut harus dibalas dengan melakukan serahan semula hasil-hasil yang dipungut contohnya cukai yang dipungut perlu diserahkan kepada Sultan. Rujuk, Mohd Sharrif Abu Samah, Modenisasi Pentadbiran Kedah 1895-1957, Sintok: UUM Press, 2012, hlm. 14 - 15.

${ }^{8}$ Sistem kerah merupakan sistem buruh paksa yang mengkehendaki rakyat mengeluarkan tenaga kerja dengan kerajaan dan sebagai pulangan setiap buruh tidak perlu membayar sewa terhadap tanah yang diusahakan. Dalam sejarah awal, sistem kerah ini sebagai satu penindasan terhadap rakyat yang terpaksa bekerja untuk golongan atasan seperti sultan dan pembesar-pembesar negeri. Kemudian, setiap tanah yang diusahakan pula dijalankan rakyat tanpa memperoleh sebarang faedah serta bayaran. Lihat, Mohd Isa Othman, Pengalaman Kedah dan Perlis Zaman Penjajahan British, Kuala Lumpur: Utusan Publications \& Distributors Sdn. Bhd, 2001, hlm. 18.

9 J. M. Gulick, "Kedah", dalam JMBRAS, Vol. 58, 2, 1985, hlm. 115. Lihat juga Foziah bt Hat, Kedah Di bawah Kepimpinan Sultan Ahmad Tajuddin (II) Mukarram Shah (1854-1879), Latihan Ilmiah, Jabatan Sejarah, Fakulti Sains Kemasyarakatan Dan Kemanusiaan, Universiti Kebangsaan Malaysia, 1990/91, hlm. 86-87.

${ }^{10}$ A. Wright \& T. H. Reid, The Malay Peninsula: A Record of British Progress In Middle East, London: T. Fisher Uwin, 1972, hlm. 184-185.

11 Surat-Menyurat Sultan Abdul Hamid, No. 5. T H. 1308-1313 (Tahun Masihi 1890-1895), 14 Syaaban 1311.

12 Sharom Ahmat, "The Political Structure of the State of Kedah, 1879-1905", Journal of Southeast Asian Studies, Vol. 1, Bhg 2, National University of Singapore, 1970, hlm. 116.

${ }_{13}$ Mohd. Isa Othman, Pengalaman Kedah dan Perlis Zaman Penjajahan British, Kuala Lumpur: Utusan Publication \& Distributor Sdn. Bhd, 2007, hlm. 70. Lihat juga Afifudin Hj. Omar, Penanaman Padi di Kedah: Sejarah Peranan Dalam Ekonomi Negeri Kedah, dalam Alor Setar 250 Tahun, Kerajaan Kedah Darul Aman, 1990, hlm. 209.

${ }^{14}$ Penghijrahan orang Cina ke Kedah menunjukkan peningkatan dari tahun ke tahun. Selepas campur tangan British kedatangan mereka dilihat terus bertambah. Berdasarkan rekod pada tahun 1911, telah mencatatkan sebanyak 33, 746 orang, kemudian 1921 jumlah orang Cina bertambah kepada 59, 403 orang, tahun 1931 pula meningkat kepada 78, 415 orang dan jumlah kedatangan orang Cina berterusan meningkat dengan positif pada tahun 1947 iaitu sebanyak 115, 928 orang. Lihat, Censuses of Population, 1911, 1921, \& 1931 dalam Zaharah Haji Mahmud, 'The Evolution of Population and Settlement in the State of Kedah', dalam Asmah Haji Omar, Darul Aman: Essays on Linguistic, Cultural and Socio-Economic Aspects of the Malaysian State of Kedah, Kuala Lumpur, 1979, hlm. 136.

${ }^{15}$ Afifuddin Hj. Omar, Pembangunan Ekonomi Kaum Tani (Suatu Kajian Ekonomi - Politik di Wilayah Muda), hlm.83.

${ }^{16}$ Mohd. Isa Othman, Pengalaman Kedah \& Perlis : Zaman Penjajahan British, hlm. 50.

${ }^{17}$ Haslindawati Binti Saari, Sejarah Perkembangan Pertanian Padi Di Kota Setar (1880 - 1940), Latihan Ilmiah, Jabatan Sejarah, Fakulti Sains Sosial dan Kemanusiaan, UPSI, 2006, hlm. 46.

${ }^{18}$ SUK.K, 3381 / 1357, Rice Mills in Kedah. Lihat juga, X. A. Wu, 'Chinese Family Business Network in the Making of a Malay State: Kedah and the Region c. 1882 - 1941', Tesis Ph.D, Faculty of Social and Behavioural Sciences, University of Amsterdam, 1999, hlm. 237-238.

${ }^{19}$ Ibid. 
${ }^{20}$ X. A. Wu, 'Chinese Family Business Network in the Making of a Malay State: Kedah and the Region c. 1882- 1941', hlm. 237.

${ }^{21}$ SUK. K 1515/1349, Apply for Loan for the Purchase of Padi and Rice for their Consumption. Rujuk Surat daripada Distressed Raayats Mukim Sala Besar kepada Tuan Setiausaha Kerajaan Negeri Kedah yang bertarikh 18 Oktober 1930.

22 J. D. Hall, Annual Report On The Social And Economic Progress Of The People Of The State Of Kedah For The Year 1356 A.H, Alor Setar: Printed At The Kedah Government Press, 1938, hlm. 26.

${ }^{23}$ Straits Settlements Original Correspondence, CO 273/307-309, Vol. 1-2, Memo By The Secretary For The Chinese Affairs In The Present Position of Affairs In Kedah, 25 January 1905.

${ }^{24}$ Padi kunca merupakan amalan kredit yang melibatkan petani Melayu. Manakala istilah umum pula merujuk kepada hutang di mana segala barang yang dipinjam akan dicagarkan dengan hasil padi sekiranya pembiayaan tidak dapat dibuat. Petani Melayu juga telah menggambarkan kesusahan yang mereka hadapi disebabkan "evils of padi kunca". Bantuan yang dihulurkan pengilang padi Cina pada peringkat awal telah menyebabkan hutang petani Melayu sentiasa meningkat. Untuk keterangan lanjut, lihat dalam Mokhzani Abdul Rahim, Credit In A Malay Peasant Economy, Kuala Lumpur : Arus Intelek Sdn. Bhd, 2006, hlm. 171-173.

${ }^{25}$ SUK. K 773/1350, Information of a Combine of Rice Mills in Kedah \& Penang to Reduce Price of Padi to \$4 a Kuncha, 1930.

${ }^{26}$ SUK. K 113/1349, Padi Planters in the Mukims of Langgar and Limbong Apply for the Purchase of Padi and Rice for their Consumption During the Time of their Preparation for the Planting Season. Rujuk Surat Penghulu Mukim Langgar dan Limbong iaitu Mohamed Saad kepada Tuan Penghulu Daerah Kota Setar bertarikh 8 September 1930.

${ }^{27}$ Lim Chong Yah, Economic Development of Modern Malaya, Oxford University Press, 1967, hlm. 171-172. Lihat juga AfifudinHj.Omar, Pembangunan Ekonomi Kaum Tani , hlm. 90.

${ }^{28}$ Haslindawati Binti Saari, Sejarah Perkembangan Pertanian Padi di Kota Setar (1880-1941), hlm. 45.

${ }^{29}$ SUK. K 930/1339, Paddy Harvest, 1930.

${ }^{30}$ Lee Say Lee, 'A Study of the Rice Trade in Kedah Before and During Japanese Occupation', Journal of the Malaysian Historical Society, No. 24, Kuala Lumpur, 1981, hlm. 111.

${ }^{31}$ Ibid.

${ }^{32}$ G. Mohamed Khan, History of Kedah, Penang : Penang Premier Press Co. Ltd, 1958, hlm. 62.

${ }^{33}$ Lee Say Lee, 'A Study of the Rice Trade in Kedah Before and During Japanese Occupation', hlm. 109.

${ }^{34}$ Ibid.

${ }^{35}$ Lee Say Lee, 'A Study of the Rice Trade in Kedah Before and During Japanese Occupation', hlm. 111-112.

${ }^{36}$ SUK. K 182/1338, Rules for Guidance of Wholesale Rice Dealers. Rujuk Surat daripada Ejen Kawalan Makanan, Kedah Mengenai Maklumat-Maklumat dan Arahan sebagai Pemegang Lesen Pemborong Beras yang Bertarikh 15.10.19.

${ }^{37}$ SUK. K 558/1338, Quantity of Rice Allowed To Retail Rice Dealer in Kulim. Rujuk Surat daripada Peniaga Cina Kulim kepada Regent, Alor Setar mengenai pengedaran beras kepada peruncit di Kulim oleh syarikat Hock Kee\& Co. yang bertarikh 26 April 1919.

${ }^{38}$ SUK. K, 2544/1350, Registration of "The Rice Millers and Padi Dealers Association". 21. 12. 1931. Lihat juga, Wu Xiao An, 'Chinese Family Business Networks in the Making a Malay State: Kedah and the Region c. 1882-1941', hlm. 223.

${ }^{39}$ SUK. K 773/1350, Information of a Combine of Rice Mills in Kedah \& Penang to Reduce Price of Padi to \$4 a Kuncha, 1930.

${ }^{40}$ Tan Ding Eing, The Rice Industry In Malaya 1920-1940, Singapore: Malaya Publishing House Limited, 1963, hlm. 44 . 